\title{
BODIPY-Au(I): A Photosensitizer for Singlet Oxygen Generation and Photodynamic Therapy
}

\author{
Muhammed Üçüncü, ${ }^{\ddagger}$ Erman Karakuş, Eylem Kurulgan Demirci, Melike Sayar, Suay Dartar, \\ and Mustafa Emrullahoğlu*(0)
}

Department of Chemistry, Faculty of Science, İzmir Institute of Technology, Urla, 35430 Izmir, Turkey

\section{Supporting Information}

ABSTRACT: Upon complexation with $\mathrm{Au}(\mathrm{I})$, a photoinactive BODIPY derivative was transformed into a highly photoactive triplet sensitizer. Along with high efficiency in singlet oxygen generation $\left(\Phi_{\Delta}=0.84\right)$, the new $\mathrm{BODIPY}-\mathrm{Au}(\mathrm{I})$ skeleton showed excellent photocytotoxic activity against cancer cell lines $\left(\mathrm{EC}_{50}=2.5 \mathrm{nM}\right)$.

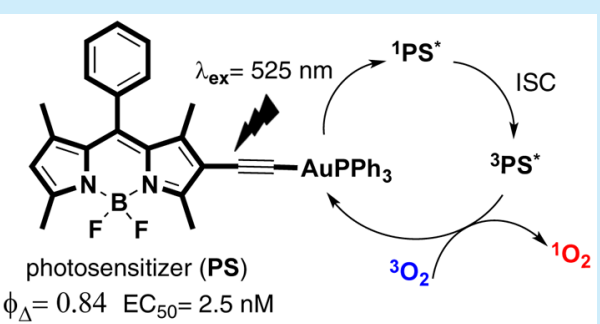

$\mathrm{T}$ he search for new classes of photosensitizers with potential applications in photodynamic therapy (PDT) has intensified significantly in the past few years. ${ }^{1}$ A wellrecognized clinical modality for treating localized cancers ${ }^{2}$ and other diseases, ${ }^{3}$ PDT involves the activation of a photosensitizer by light to generate cytotoxic reactive oxygen species (e.g., singlet oxygen) within cells to promote irreversible cellular damage and cell death. The critical component of PDT is the photosensitizer, which should have a high capacity for singlet oxygen generation, absorption bands within the therapeutic window, and the ability to colocalize in cancer tissue.

Most photosensitizers investigated in clinical trials comprise cyclic tetrapyrrole structures inspired by naturally derived porphyrins such as hematoporphyrin. ${ }^{1 \mathrm{~d}, 4}$ Although synthetic dyes not of porphyrin origin have also been evaluated for their photosensitizing abilities, ${ }^{5}$ they suffer from drawbacks such as dark cytotoxicity and photobleaching.

As an alternative class to nonporphyrin-based photosensitizers, the boron-dipyrromethene (BODIPY) dye platform has also been subject to extensive study. ${ }^{6}$ BODIPY dyes have certain characteristics, including high extinction coefficients, robustness toward light and chemicals, and resistance to photobleaching, that make them good candidates as photosensitizers for PDT. ${ }^{7}$ However, deprived of excited triplet states, which represent a key photophysical parameter necessary for generating singlet oxygen from molecular oxygen, the unmodified BODIPY core (e.g., tetramethyl-BODIPY) remains photoinactive.

Recent studies on BODIPY-based photosensitizers have elegantly demonstrated that the controlled manipulation of the BODIPY core could precipitate intriguing photophysical changes. $^{8}$ In that context, Nagano, ${ }^{9}$ Akkaya, ${ }^{10}$ O'Shea, ${ }^{11}$ and McClenaghan, ${ }^{12}$ as well as other researchers, ${ }^{13}$ have clearly established that placing heavy atoms (e.g., bromine or iodine) at appropriate positions on the primary BODIPY core can promote spin-orbit coupling, which allows the sort of intersystem crossing (ISC) needed to observe triplet states (Scheme 1a).

Scheme 1. BODIPY-Based Photosensitizers for ${ }^{1} \mathrm{O}_{2}$ Generation
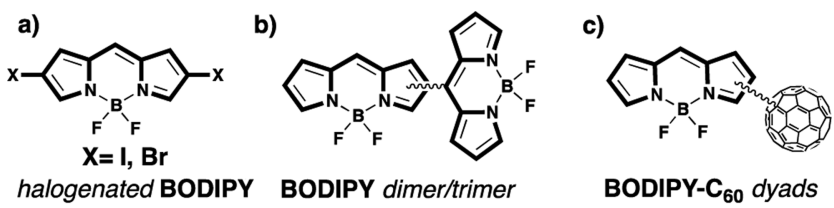

d)
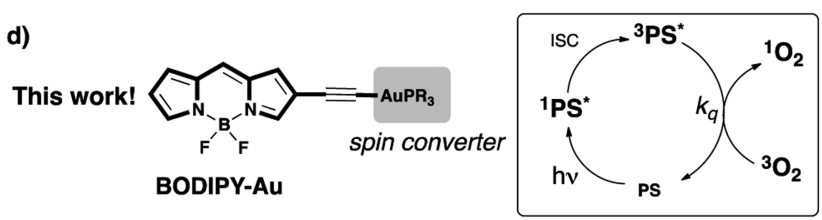

As alternatives to heavy atom-bearing BODIPY dyes, orthogonal BODIPY dimers and trimers have been reported by Akkaya et al. $^{14}$ and Zhang et al. ${ }^{15}$ to be exceptionally effective photosensitizers for singlet oxygen generation (Scheme 1b). In contrast, Zhao et al. have identified BODIPY $-\mathrm{C}_{60}$ as a heavy atom-free organic triplet sensitizer that uses $\mathrm{C}_{60}$ as a spin converter (Scheme $\left.1 \mathrm{c}\right){ }^{16}$

Introducing transition-metal ions in close proximity to a fluorophore skeleton is another approach to enabling the observation of excited triplet states. In that context, a range of transition-metal complexes of BODIPY-based luminophores have been designed and investigated as triplet photosensitizers. ${ }^{17-21}$ Nevertheless, to the best of our knowledge, using a

Received: March 16, 2017

Published: May 9, 2017 
BODIPY-Au(I) complex as a singlet oxygen generator has yet to be examined.

To develop a new chemical construct as an efficient singlet oxygen generator, we designed a BODIPY dye platform comprising $-\mathrm{LAu}(\mathrm{I})\left(\mathrm{L}=\mathrm{PPh}_{3}\right)$ as a potential spin converter $\left(\mathrm{S}_{1}-\mathrm{T}_{1}\right)$ (Scheme $\left.1 \mathrm{~d}\right)$. We anticipated that incorporating $-\mathrm{LAu}(\mathrm{I})$ into the alkynyl backbone of a BODIPY core would enhance the probability of ISC due to the heavy atom effect of $\mathrm{Au}(\mathrm{I})$ and thereby improve the possibility to observe excited triplet states.

Herein, we present the design, synthesis, and spectroscopic investigation of a BODIPY-Au(I) construct, denoted as BOD-Au, which allows for exceptionally rapid, highly efficient singlet oxygen generation both in solution and living environments. We also established the construct's great potential for use as a cytotoxic agent in PDT.

We prepared BOD-Au synthetically, as outlined in Scheme 2. We treated the individually prepared acetylene derivative of

Scheme 2. Synthesis of BOD-Au

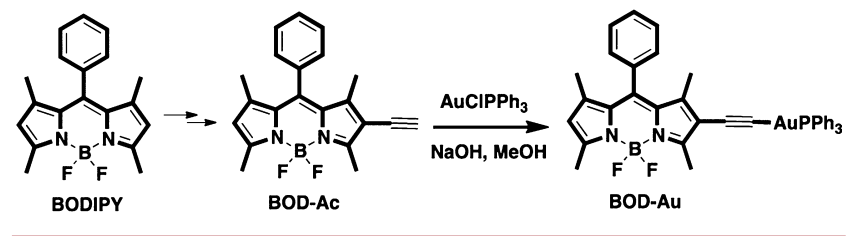

BODIPY (BOD-Ac) in methanol with $\mathrm{AuClPPh}_{3}$ in the presence of a base (i.e., $\mathrm{NaOH}$ ) to generate the compound in a reasonable yield of approximately $75 \%$. We adopted recrystallization as the protocol for purification since we observed decomposition during chromatography on $\mathrm{SiO}_{2}$. We confirmed the identity of the title compound via nuclear magnetic resonance spectroscopy and high-resolution mass spectrometric analysis. $^{22}$

We investigated the spectroscopic behavior of BOD-Au and its ability to generate singlet oxygen by fluorescence and absorption spectroscopy. Table 1 shows the electronic absorption and emission data of BOD-Au and, for comparison, of the gold-ion-free derivative BOD-Ac.

Table 1. Photophysical Parameters of BOD-Ac, BOD-Au, and $2 \mathrm{I}-\mathrm{BOD}$

$\begin{array}{lllllll}\text { compd }^{a} & \lambda_{\mathrm{abs}} & \varepsilon^{b} & \lambda_{\mathrm{em}} & \Phi_{\mathrm{F}}{ }^{c} & \tau_{\mathrm{F}}(\mathrm{ns})^{d} & \Phi_{\Delta}{ }^{e} \\ \text { BOD-Ac } & 518 & 5.1 & 535 & 0.58 & 5.38 & \mathrm{na}^{g} \\ \text { BOD-Au } & 550 & 3.8 & 583 & 0.05 & 1.02 & 0.84 \\ \text { 2I-BOD } & 529 & 8.5 & 548 & 0.03 & 0.13^{f} & 0.79\end{array}$

${ }^{a}$ In $\mathrm{CH}_{2} \mathrm{Cl}_{2}\left(5 \times 10^{-6} \mathrm{M}\right) .{ }^{b}$ Molar absorption coefficient at the absorption maximum, $\varepsilon$ : $10^{4} \mathrm{M}^{-1} \mathrm{~cm}^{-1}$. ${ }^{c}$ With rhodamine $\mathrm{B}$ as standard $\left(\Phi_{\mathrm{F}}=0.31\right.$ in $\left.\mathrm{H}_{2} \mathrm{O}\right) .{ }^{d}$ Fluorescence lifetimes ${ }^{e}$ Singlet oxygen $\left({ }^{1} \mathrm{O}_{2}\right)$ quantum yield. ${ }^{f}$ In $\mathrm{CH}_{3} \mathrm{CN}^{23}{ }^{g}$ Not applicable.

As Figure 1 reveals, the absorption spectra of BOD-Ac is dominated by a maximum band at approximately $520 \mathrm{~nm}$ belonging to spin-allowed $\pi-\pi^{*}$ transitions of the BODIPY core. For BOD-Au, the absorption band was significantly redshifted compared to its metal-free analogue, which clearly indicated a perturbation on the $\pi$-conjugation. Upon excitation at $540 \mathrm{~nm}\left(\mathrm{CH}_{2} \mathrm{Cl}_{2}, 5 \mu \mathrm{M}\right), \mathbf{B O D}-\mathbf{A u}$ also exhibited a redshifted emission band in the visible region, albeit with a far smaller fluorescence quantum yield $\left(\Phi_{\mathrm{F}}=0.05, \tau_{\mathrm{F}} /(\mathrm{ns})=1.02\right)$
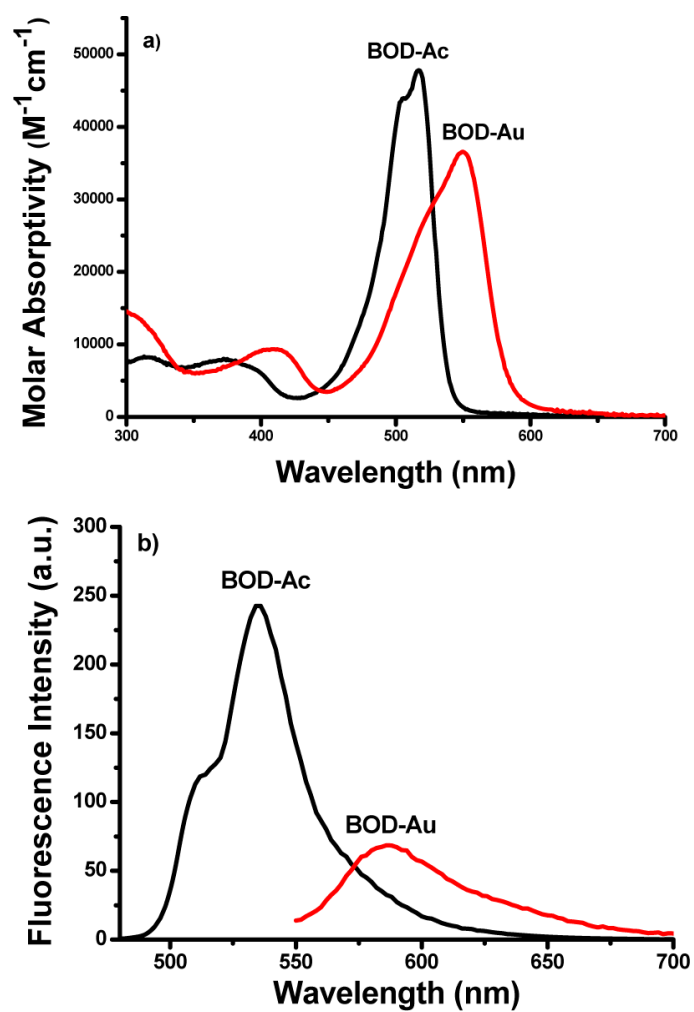

Figure 1. (a) Absorption spectra of BOD-Ac $(5 \mu \mathrm{M})$ and BOD-Au (5 $\mu \mathrm{M})$ in $\mathrm{CH}_{2} \mathrm{Cl}_{2}$; (b) emission spectra of BOD-Ac $(5 \mu \mathrm{M})$ and BODAu $(5 \mu \mathrm{M})$ in $\mathrm{CH}_{2} \mathrm{Cl}_{2}\left(\lambda_{\mathrm{ex}}: 460 \mathrm{~nm}\right.$ for BOD-Ac, $\lambda_{\mathrm{ex}}: 540 \mathrm{~nm}$ for BOD-Au).

and briefer fluorescence lifetime than that of BOD-Ac $\left(\Phi_{\mathrm{F}}=\right.$ $\left.0.58, \tau_{\mathrm{F}} /(\mathrm{ns})=5.38\right)$, as Table 1 shows.

Although a detailed investigation of the excited-state properties of BOD-Au remains necessary (e.g., via transient absorption spectroscopy), a sharp decrease in $\Phi_{\mathrm{F}}$ and briefer decay time of the singlet excited state indicated ISC promoted by the internal heavy atom effect of $\mathrm{Au}(\mathrm{I})$. Importantly, BODAu displayed no phosphorescence at either room temperature or $77 \mathrm{~K}$. Similar results for some transition-metal-ion complexes of BODIPY dyes have been observed by other researchers as well. $^{21,24}$

To confirm that BODIPY can generate $\mathrm{T}_{1}$ states via ISC, a reasonable approach is to use molecular oxygen as a triplet acceptor, which in turn generates singlet oxygen via triplettriplet state energy transfer. To that end, we assessed the capabilities of BOD-Au and BOD-Ac to generate singlet oxygen by employing a trapping method using diphenylisobenzofuran (DPBF) to trap ${ }^{1} \mathrm{O}_{2}$. Singlet oxygen interacts with DPBF to yield 1,2-dibenzoylbenzene, and the extent of DPBFrelated photodegradation can be evaluated by measuring the decrease in the DPBF absorption band at $415 \mathrm{~nm}$ (Figure 2).

For BOD-Ac, we detected no signs of DPBF photodegradation, whereas for BOD-Au, absorbance at $415 \mathrm{~nm}$ decreased remarkably and disappeared entirely within a couple of minutes, which clearly demonstrates its high efficiency in generating ${ }^{1} \mathrm{O}_{2}$. The efficiency of generating singlet oxygen, known as singlet oxygen quantum yield, has a remarkably high $\Phi_{\Delta}$ value (Table 1), calculated with diiodo-BODIPY (2I$\mathbf{B O D}^{23}$ ) as the reference. ${ }^{22}$ Our findings show that BOD-Au is one of the most efficient BODIPY-based singlet oxygen generator developed thus far. Meanwhile, the absorbance of 

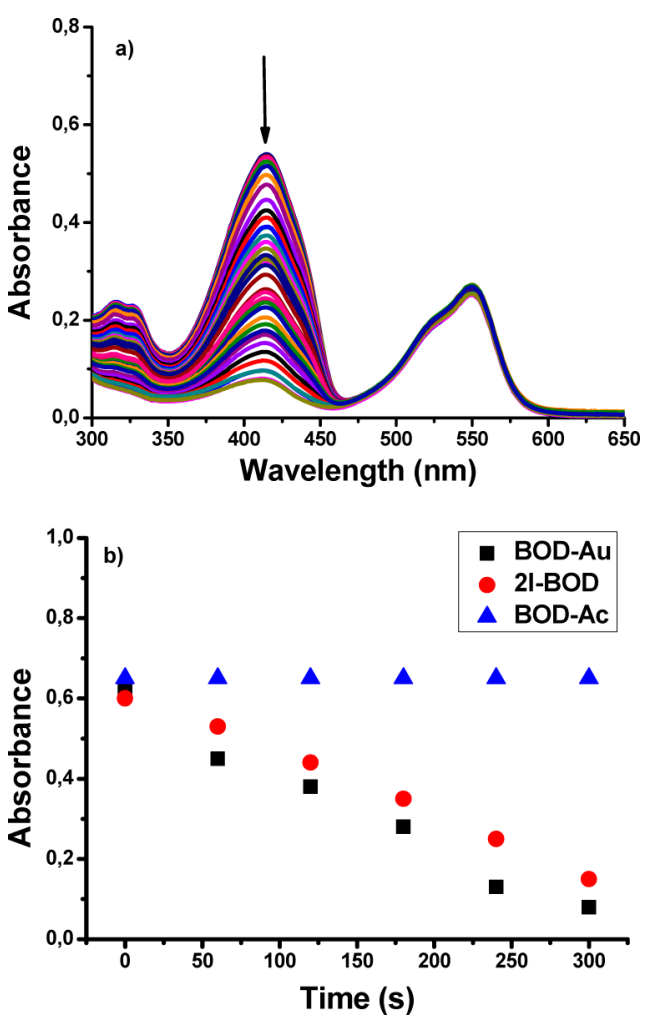

Figure 2. (a) Singlet oxygen mediated bleaching of DPBF in the presence of BOD-Au $\left(5 \mu \mathrm{M}\right.$ in $\left.\mathrm{CH}_{2} \mathrm{Cl}_{2}\right)$. (b) Comparison of the rates of decay of DPBF $(25 \mu \mathrm{M})$ in $\mathrm{CH}_{2} \mathrm{Cl}_{2}$, as monitored at $415 \mathrm{~nm}$, using BOD-Ac, BOD-Au as the photosensitizers $(5 \mu \mathrm{M})$ and 2I-BOD (5 $\mu \mathrm{M})$ as the reference. Irradiation using green LED $\left(3.3 \mathrm{~mW} / \mathrm{cm}^{2}\right)$ emitting at $\lambda_{\mathrm{em}}=525 \mathrm{~nm}$ at the distance of $15 \mathrm{~cm}$ from the cuvette window.

BOD-Au at $550 \mathrm{~nm}$ remained stable during the irradiating process, thus proving its high resistance to photobleaching (Figure 2a).

The promising efficiency of $\mathbf{B O D}-\mathbf{A u}$ in generating singlet oxygen in the solution encouraged us to further assess its in vitro photocytotoxic activity against cancer cell lines. To ascertain the subcellular localization of BOD-Au within A549 cells and observe whether any correlation exists with MTT assay results, we first studied its subcellular localization within A549 cells by using LysoTracker as an organelle-specific fluorescent dye to stain the lysosomes. Although the fluorescence emission of BOD-Au was relatively weak in the solution, it was sufficient for its visualization in the cellular medium. Based on the counter stain and green fluorescence emitting from the cells, we thus conclude that the BOD-Au passes through the cell membrane and localizes particularly in the cytosol (Figure 3).

The photodynamic activity of BOD-Au in Tween 80 emulsions was investigated against A549 cells by using MTT assay. ${ }^{22}$ We first loaded A549 cells with BOD-Au, irradiated them with green light (green LED, $525 \mathrm{~nm}, 3.3 \mathrm{~mW} / \mathrm{cm}^{2}$ ) for 5-30 min, and incubated them for $48 \mathrm{~h}$ in the dark. We protected another group of A549 cells from light throughout the incubation process in order to explore the effect of light on the activity of BOD-Au.

For cell lines illuminated by green light, we observed a significant decrease in viability even at very low concentrations of $\mathbf{B O D}-\mathbf{A u}\left(\mathrm{EC}_{50}=2.5 \mathrm{nM}\right)$, as the red bars in Figure 4 show.

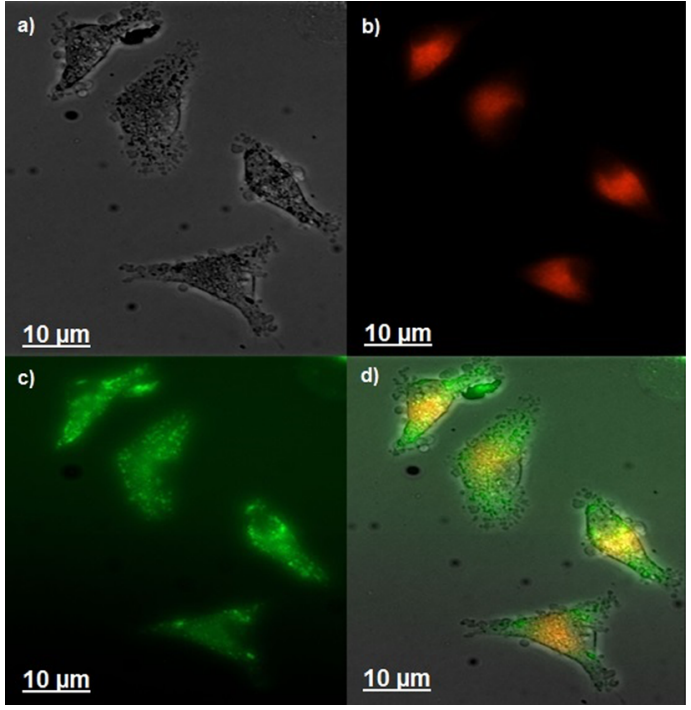

Figure 3. Fluorescence images of human lung adenocarcinoma cells (A549). (a) Bright field image of A549 cells treated with only BODAu $(10 \mu \mathrm{M})$; (b) fluorescence image of cells treated with Lyso-tracker (control); (c) fluorescence image of cells treated with BOD-Au (10 $\mu \mathrm{M})$; (d) merged images of a-c.

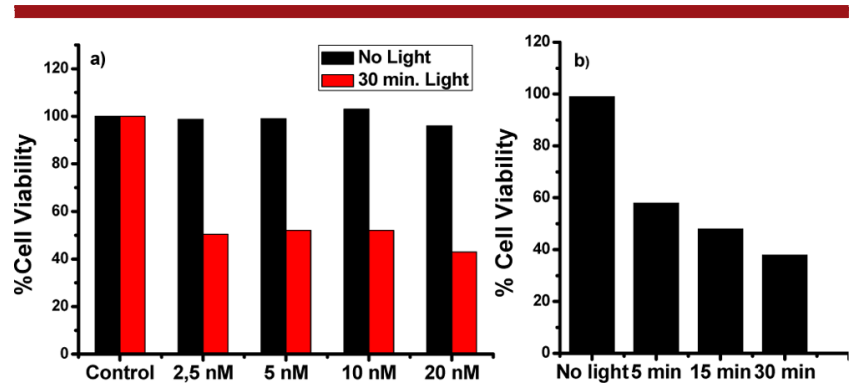

Figure 4. (a) Cell viability of A549 cells after treatment with BOD$\mathrm{Au}$ at different concentrations $(2.5,5,10$, and $20 \mathrm{nM})$. Control group was incubated only with the cell culture medium. (b) Effect of light dose on cell viability (BOD--Au, $20 \mathrm{nM}$ ).

For cell lines kept in the dark, however, BOD-Au showed no significant cytotoxicity at concentrations up to $40 \mathrm{nM}\left(\mathrm{IC}_{50}=\right.$ $0.16 \mu \mathrm{M}){ }^{22}$ We also examined the change in cell viability as a function of the light dosage; results clearly showed that the extent of light illumination is critical to the photodynamic efficiency of the photosensitizer.

In summary, we devised a photosensitizer comprising a BODIPY dye as a visible light-harvesting chromophore and $-\mathrm{LAu}(\mathrm{I})\left(\mathrm{L}=\mathrm{PPh}_{3}\right)$ as a spin convertor $\left(\mathrm{S}_{1}-\mathrm{T}_{1}\right)$. By introducing $-\mathrm{LAu}(\mathrm{I})$ into the backbone of a BODIPY dye, we transformed a photoinactive dye into a highly photoactive triplet sensitizer. In line with its high singlet oxygen generation efficiency $\left(\Phi_{\Delta}=0.84\right)$, this new BODIPY-based photosensitizer showed excellent photocytotoxic activity against cancer cell lines $\left(\mathrm{EC}_{50}=2.5 \mathrm{nM}\right)$.

\section{ASSOCIATED CONTENT}

\section{Supporting Information}

The Supporting Information is available free of charge on the ACS Publications website at DOI: 10.1021/acs.orglett.7b00791.

Absorbance, fluorescence, and characterization data and experimental procedures (PDF) 


\section{AUTHOR INFORMATION}

\section{Corresponding Author}

*E-mail: mustafaemrullahoglu@iyte.edu.tr. ORCID $\odot$

Mustafa Emrullahoğlu: 0000-0002-8221-2597

Author Contributions

${ }^{\ddagger}$ M.Ü. and E.K. contributed equally.

Notes

The authors declare no competing financial interest.

\section{ACKNOWLEDGMENTS}

We thank İzmir Institute of Technology (IZTECH) and Turkish Academy of Science, Outstanding Young Scientist Award (TUBA-GEBIP-2016), for financial support and İzmir Institute of Technology, Biotechnology and Bioengineering Research and Application Centre for fluorescence imaging facilities.

\section{REFERENCES}

(1) (a) Bonnet, R. Chemical Aspects of Photodynamic Theraphy; Gordon and Breach Science: Amsterdam, 2000. (b) Yano, S.; Hirohara, S.; Obata, M.; Hagiya, Y.; Ogura, S.-I.; Ikeda, A.; Kataoka, H.; Tanaka, M.; Joh, T. J. Photochem. Photobiol., C 2011, 12, 46-67. (c) Patrice, T. Photodynamic Therapy; The Royal Society of Chemistry, 2003; Book 2. (d) Sharman, W. M.; Allen, C. M.; Van Lier, J. E. Drug Discovery Today 1999, 4, 507-517.

(2) (a) Dougherty, T. J.; Gomer, C. J.; Henderson, B. W.; Jori, G.; Kessel, D.; Korbelik, M.; Moan, J.; Peng, Q. J. Natl. Cancer Inst. 1998, 90, 889-905. (b) Dougherty, T. J. J. Hematother. 2002, 20, 3-7. (c) Juzeniene, A.; Peng, Q.; Moan, J. Photochem. Photobiol. Sci. 2007, 6, 1234-1245.

(3) (a) Babilas, P.; Schreml, S.; Landthaler, M.; Szeimies, R. M. Photodermatol., Photoimmunol. Photomed. 2010, 26, 118-132. (b) Kossodo, S.; LaMuraglia, G. M. Am. J. Cardiovasc. Drugs 2001, 1, 15-21. (c) Garrier, J.; Bezdetnaya, L.; Barlier, C.; Gräfe, S.; Guillemin, F.; D’Hallewin, M.-A. Photodiagn. Photodyn. Ther. 2011, 8, 321-327.

(4) (a) Dougherty, T. J.; Grindey, G. B.; Fiel, R.; Weishaupt, K. R.; Boyle, D. G. JNCI J. Natl. Cancer Inst. 1975, 55, 115-121. (b) Kelly, J. F. Proc. R. Soc. Med. 1975, 68, 527-528. (c) Kelly, J. F.; Snell, M. E.; Berenbaum, M. C. Br. J. Cancer 1975, 31, 237-44.

(5) (a) Wainwright, M. Chem. Soc. Rev. 1996, 25, 351-359. (b) Dolmans, D. E. J. G. J.; Fukumura, D.; Jain, R. K. Nat. Rev. Cancer 2003, 3, 380-387. (c) Bonnett, R. Chem. Soc. Rev. 1995, 24, 19-33. (d) Sternberg, E. D.; Dolphin, D.; Bruckner, C. Tetrahedron 1998, 54, 4151-4202. (e) Nyman, E. S.; Hynninen, P. H. J. Photochem. Photobiol., B 2004, 73, 1-28.

(6) (a) Awuah, S. G.; You, Y. RSC Adv. 2012, 2, 11169-11183. (b) Kamkaew, A.; Lim, S. H.; Lee, H. B.; Kiew, L. V.; Chung, L. Y.; Burgess, K. Chem. Soc. Rev. 2013, 42, 77-88.

(7) (a) Loudet, A.; Burgess, K. Chem. Rev. 2007, 107, 4891-4932. (b) Boens, N.; Leen, V.; Dehaen, W. Chem. Soc. Rev. 2012, 41, 11301172 .

(8) Li, X.; Kolemen, S.; Yoon, J.; Akkaya, E. U. Adv. Funct. Mater. 2017, 27, No. 1604053.

(9) Yogo, T.; Urano, Y.; Ishitsuka, Y.; Maniwa, F.; Nagano, T. J. Am. Chem. Soc. 2005, 127, 12162-12163.

(10) (a) Ozlem, S.; Akkaya, E. U. J. Am. Chem. Soc. 2009, 131, 4849. (b) Erbas, S.; Gorgulu, A.; Kocakusakogullari, M.; Akkaya, E. U. Chem. Commun. 2009, 4956-4958.

(11) (a) Gallagher, W. M.; Allen, L. T.; O'Shea, C.; Kenna, T.; Hall, M.; Gorman, A.; Killoran, J.; O'Shea, D. F. Br. J. Cancer 2005, 92, 1702-1710. (b) Killoran, J.; Allen, L.; Gallagher, J. F.; Gallagher, W. M.; O'Shea, D. F. Chem. Commun. 2002, 24, 1862-1863. (c) Gorman,
A.; Killoran, J.; O’Shea, C.; Kenna, T.; Gallagher, W. M.; O'Shea, D. F. J. Am. Chem. Soc. 2004, 126, 10619-10631.

(12) Batat, P.; Cantuel, M.; Jonusauskas, G.; Scarpantonio, L.; Palma, A.; O'Shea, D. F.; McClenaghan, N. D. J. Phys. Chem. A 2011, 115, 14034-14039.

(13) Adarsh, N.; Avirah, R. R.; Ramaiah, D. Org. Lett. 2010, 12, $5720-5723$

(14) (a) Cakmak, Y.; Kolemen, S.; Duman, S.; Dede, Y.; Dolen, Y.; Kilic, B.; Kostereli, Z.; Yildirim, L. T.; Dogan, A. L.; Guc, D.; Akkaya, E. U. Angew. Chem., Int. Ed. 2011, 50, 11937-11941. (b) Duman, S.; Cakmak, Y.; Kolemen, S.; Akkaya, E. U.; Dede, Y. J. Org. Chem. 2012, 77, 4516-4527. (c) Kolemen, S.; Işık, M.; Kim, G. M.; Kim, D.; Geng, H.; Buyuktemiz, M.; Karatas, T.; Zhang, X.-F.; Dede, Y.; Yoon, J.; Akkaya, E. U. Angew. Chem., Int. Ed. 2015, 54, 5340-5344. (d) Ozdemir, T.; Bila, J. L.; Sozmen, F.; Yildirim, L. T.; Akkaya, E. U. Org. Lett. 2016, 18, 4821-4823.

(15) (a) Zhang, X.-F.; Yang, X. J. Phys. Chem. B 2013, 117, 55335539. (b) Pang, W.; Zhang, X.-F.; Zhou, J.; Yu, C.; Hao, E.; Jiao, L. Chem. Commun. 2012, 48, 5437-5439. (c) Zhang, X.-F.; Yang, X. J. Phys. Chem. B 2013, 117, 9050-9055.

(16) Huang, L.; Yu, X.; Wu, W.; Zhao, J. Org. Lett. 2012, 14, 25942597.

(17) (a) Galletta, M.; Campagna, S.; Quesada, M.; Ulrich, G.; Ziessel, R. Chem. Commun. (Cambridge, U. K.) 2005, 4222-4224. (b) Wu, W.; Sun, J.; Cui, X.; Zhao, J. J. Mater. Chem. C 2013, 1, 4577-4589.

(18) Sun, J.; Zhong, F.; Yi, X.; Zhao, J. Inorg. Chem. 2013, 52, 62996310.

(19) (a) Nastasi, F.; Puntoriero, F.; Campagna, S.; Diring, S.; Ziessel, R. Phys. Chem. Chem. Phys. 2008, 10, 3982-3986. (b) Nastasi, F.; Puntoriero, F.; Serroni, S.; Campagna, S.; Olivier, J.-H.; Ziessel, R Dalt. Trans. 2014, 43, 17647-17658. (c) Wu, W.; Zhao, J.; Guo, H.; Sun, J.; Ji, S.; Wang, Z. Chem. - Eur. J. 2012, 18, 1961-1968. (d) Wu, W.; Liu, L.; Cui, X.; Zhang, C.; Zhao, J. Dalton Trans. 2013, 42, 14374-14379. (e) Lazarides, T.; McCormick, T. M.; Wilson, K. C.; Lee, S.; McCamant, D. W.; Eisenberg, R. J. Am. Chem. Soc. 2011, 133, 350-364. (f) Sabatini, R. P.; Zheng, B.; Fu, W. F.; Mark, D. J.; Mark, M. F.; Hillenbrand, E. A.; Eisenberg, R.; McCamant, D. W. J. Phys. Chem. A 2014, 118, 10663-10672.

(20) Yi, X.; Zhao, J.; Sun, J.; Guo, S.; Zhang, H. Dalt. Trans. 2013, 42, 2062-2074.

(21) (a) Zhao, J.; Xu, K.; Yang, W.; Wang, Z.; Zhong, F. Chem. Soc. Rev. 2015, 44, 8904-8939. (b) Zhao, J.; Ji, S.; Guo, H. RSC Adv. 2011, $1,937-950$.

(22) See the Supporting Information.

(23) Wu, W.; Guo, H.; Wu, W.; Ji, S.; Zhao, J. J. Org. Chem. 2011, 76, $7056-7064$.

(24) (a) Chan, K. T.; Tong, G.; To, W.-P.; Yang, C.; Du, L.; Phillips, D. L.; Che, C.-M. Chem. Sci. 2017, 8, 2352-2364. (b) Maity, A.; Sarkar, A.; Sil, A.; B. N., S. B.; Patra, S. K. New J. Chem. 2017, 41, 2296-2308. 